Article

\title{
Academic Publishing: Making the Implicit Explicit
}

\author{
Cecile Badenhorst * and Xiaolin Xu \\ Faculty of Education, Memorial University, Newfoundland, A1B 3X8, Canada; xx1136@mun.ca \\ * Correspondence: cbadenhorst@mun.ca ; Tel.: +11-709-864-7654 \\ Academic Editor: Yin Ling Cheung \\ Received: 24 May 2016; Accepted: 19 July 2016; Published: 22 July 2016
}

\begin{abstract}
For doctoral students, publishing in peer-reviewed journals is a task many face with anxiety and trepidation. The world of publishing, from choosing a journal, negotiating with editors and navigating reviewers' responses is a bewildering place. Looking in from the outside, it seems that successful and productive academic writers have knowledge that is inaccessible to novice scholars. While there is a growing literature on writing for scholarly publication, many of these publications promote writing and publishing as a straightforward activity that anyone can achieve if they follow the rules. We argue that the specific and situated contexts in which academic writers negotiate publishing practices is more complicated and messy. In this paper, we attempt to make explicit our publishing processes to highlight the complex nature of publishing. We use autoethnographic narratives to provide discussion points and insights into the challenges of publishing peer reviewed articles. One narrative is by a doctoral student at the beginning of her publishing career, who expresses her desires, concerns and anxieties about writing for publication. The other narrative focuses on the publishing practices of a more experienced academic writer. Both are international scholars working in the Canadian context. The purpose of this paper is to explore academic publishing through the juxtaposition of these two narratives to make explicit some of the more implicit processes. Four themes emerge from these narratives. To publish successfully, academic writers need: (1) to be discourse analysts; (2) to have a critical competence; (3) to have writing fluency; and (4) to be emotionally intelligent.
\end{abstract}

Keywords: graduate student publishing; scholarly publication; research writing; productive academic writing; academic publishing; autoethnography

\section{Introduction}

Publishing while completing graduate studies has become an additional burden for doctoral students and many students are under enormous pressure to publish. The message they receive from supervisors, new faculty and the job market is that their academic future is dependent on peer-reviewed publications. The growth in popularity of the thesis-by-publication is further testament to these pressures [1]. Yet most doctoral programmes provide little in the way of pedagogical support for students to meet these demands for greater output [2,3]. Having research published, which is often portrayed as "commonsensical by experienced scholars" [4], is obscure and perplexing for many graduate students. Alongside the current flourishing interest in graduate thesis and research writing, graduate student publishing support and pedagogies is a topic that is moving centre-stage (see [5]).

How to write for publication and how to publish successfully remains tacit knowledge in the minds and practices of productive academic writers. Not all academic writers are productive or familiar with the "commonsensical" knowledge, and as McGrail, Rickard, and Jones [6] show, only a small number of faculty publish productively. Many struggle through trial and error, lack of confidence and low expectations of success. Tacit knowledge works at the unspoken and implied level. This type of knowledge develops as writers figure out how to work the system—sometimes through 
the help of mentors and sometimes on their own. Meanwhile others flounder their whole careers. Not making these tacit processes explicit contributes to an environment of invisible exclusiveness where those who 'know' become privileged and those who do not are forever held at the margins [3]. In the absence of publishing pedagogies, these inequities will continue to persist. Given the current pressure on doctoral students to publish, writing for publication should be an integral part of any doctoral program [7]. In this paper, we use two narratives, one from an experienced scholar and the other from a doctoral candidate, both in the Faculty of Education, to explore experiences of publishing to try to bring to the surface some of the tacit knowledge around publishing. By making our writing processes and concerns more explicit, we hope that newcomers will be able to draw on our experiences, find comfort and, perhaps, useful strategies to use. Even though we aim to make our writing processes more explicit we note that writing takes place in situated contexts and it is difficult to be explicit about the specific discourses and social contexts that shape individual experiences of publishing.

\section{Methodology}

In this paper we use autoethnography as our methodology. Autoethnography "is an autobiographical genre of writing and research that displays multiple layers of consciousness, connecting the personal to the cultural" [8] (p. 739). Autoethnography involves the individual becoming aware of one's own position and creating a space to change. Although autoethnography is about the self, it is not totally about the self, but the spaces between self, practice and broader society $[9,10]$. Through this methodology we connect the self with others, the self with the social and the self with the context. The individual is located among others-others of similarity, difference, and opposition [11]. In this paper, we have used the first and third person to illustrate the movement between the self and the social. There are three reasons why we think this methodology is fitting for this topic: (1) autoethnography has been used extensively to explore academic identity; (2) the practice of writing is closely tied to notions of identity and self; and (3) the methodology allows us to embraces the messiness and complexity of human life.

Autoethnography and academic identity: Autoethnography has been used extensively to explore academic identity. Many scholars have used this methodology to reflect how we have learned to be the scholars we are [12-14]. The presence of the researcher's life experience is acknowledged through autoethnographic writing [15]. As Denzin [16] has argued: "Our research practices are performative, pedagogical and political. Through our writing and our talk, we enact the worlds we study".

Writing and identity: Arnold [17] suggests that all academic writing is at some level, autobiographical. Academic writing also involves developing academic identities through participating in disciplinary discourses. It makes sense to use the self as data in a paper on academic writing and publishing since writing is intimate, personal and embodied. It is an especially useful endeavor for those who are or feel silenced by dominant discourses and cultures [13]. Autoethnography allows us to reposition ourselves. One tells one's stories to reclaim a marginalized and self-reflective space.

Messiness and complexity: Using the 'self' as methodology and as data allows us to "explore ourselves in the process of exploring ideas, practices, and scholarly questions" so as to engage in academic practice [17] (p. 65). This post-modern perspective of research and methodology brings to the surface the fragmented nature of knowing in a discursive world that is socially constructed. It embraces the messiness and complexity of human life. It recognizes the false distance we often impose as researchers between ourselves and our data [17]. Writing about the self also concedes all claims to 'fact' in writing. All we can know, for certain, is what we actualize and enact. Through this method we acknowledge the situatedness of knowledge, and how knowledge is located within particular social practices. Personal stories express "a [tentative] perspective on membership of a group" that is able to capture the disconnections, ambiguities and ruptures in academic life [18] (p. 116). Telling our story forces us to create some form of coherence through ordering our lives but "new selves form within us as we tell and re-tell our stories" [19]. Overall, autoethnography creates a vulnerability and openness that hopefully will create a resonance among readers and can potentially 
increase a sense of community and connectivity. In this paper we adopt autoethnography as the methodology to reveal the complex issues about academic publishing that often remain unsaid and to access broader social issues that influence our experiences of publishing.

\section{From the Generic 'How To' to Writing as a Social Practice}

Where can students learn how to publish papers? Many journals publish 'how to' publish papers. These generally centre on (1) genre; (2) the publishing process; and (3) advice from specific journal editors. The articles that focus on genre tend to explain the format, structure and language of academic articles (see [20-25]). Many of these papers are published in professional journals, for example, healthcare journals where it is openly acknowledged that practitioners would need explicit instruction on how to publish. Dimitroulis's paper [22] is illustrative of this type of article. It is written for surgeons and contains an argument about why practicing surgeons should publish, what they should publish and what evidence they would need to provide to be successful in publishing. For example, in a section called "What makes a good manuscript?", the author outlines the IMRD (Introduction, Materials and Methods, Results and Discussion) format for journal articles which is popular in many disciplines including the sciences, health sciences and engineering. The author states: "All full-length articles must follow the fundamental IMRD formula" [22] (p. 1344, emphasis added). Later on he writes: "The Materials and Methods section must be clear enough to enable independent third parties to repeat the experiment" [22] (p. 1344, emphasis added). While understanding the genre of journal articles is certainly recommended for newcomers to publishing, the problem with these articles is that they present a static single view of writing and publishing. Following the IMRD model as it is presented here seems straightforward, universal and unproblematic. It is also presented as the only model available to writers in the health sciences. Sollaci and Pereira [26], in their 50-year study of the IMRAD structure, show that it was only in the 1980s that this format began to dominate journal articles in the health sciences. While this genre may be popular now, this study indicates that formats and patterns for writing research articles continually change over time. Kuteeva and McGrath [27] further show how disciplinary research practices can result in variations of common research genres. In addition, a study by Lin and Evans [28] illustrates how the IMRAD pattern itself is often changed and adapted to suit the researcher, research, discipline and publication.

The articles that focus on the publishing process outline the steps needed to follow in getting an article published (see $[21,29,30])$. An illustrative example of this group of papers is the article by Derntl [21], who begins with a detailed presentation of the genre of scientific papers and then moves into publishing papers. Here he outlines the roles involved in the publishing process (reviewer, editor-in-chief, associate editor, managing editor, publisher). The article also contains a detailed description including a diagram of the possible routes (accept, accept with revisions and reject) a paper may take on the road to publication. He also discusses a number of types of publications such as special issues and conference proceedings. While this is a detailed and comprehensive description of how a paper gets published and is useful for those who are new to publishing, it also presents a view of the process as being transparent and benign. Little is mentioned of the discourses, power dynamics and geopolitics of the publishing business.

The third group of papers are those articles published by editors of journals. In these papers, which contain advice from specific journal editors, the focus tends to be on how to publish in this particular journal (see [4,31-35]). For example, Harper [32] writes specifically about publishing in a journal devoted to racial issues. The advice here is on how to develop a research idea or problem from a race-conscious worldview. This article also directs writers on how to consider issues and concerns related to research that involves participants of colour. These articles tend to focus on the discourse - the ways of knowing (epistemologies) - particular to the journal. As such they provide useful advice to newcomers on how to get published in a specific journal rather than suggesting that there is a generic approach to publishing. 
All the papers in the groups presented above overlap to some extent. The common thread that binds them is that, even though these papers are useful, they present a picture of publishing as a transparent step-by-step process where one merely needs to follow the steps, be disciplined and one will get published. Glasper and Peate [36], for example, state that they demystify the publishing process: "Writing for publication is a skill that anyone with the right amount of determination and application can learn. There is no mystery or magic" (p. 964). Lunt and Davidson [37] aim to present a straightforward publication route that any beginner can follow in their paper. They situate their argument in this way: "For many wanting to get started, it seems like the final destination is a secret place, somewhere that you might stumble across but one where the locals jealously guard the short-cuts. Here we aim to de-mystify journal article writing and provide 20 steps for the prospective writer" (p. 43). Although they do have the caveat that "those 20 steps ... provide more a series of useful directions than a definitive map of the terrain" (p. 43), the message is that if you follow these steps, you will get published. What is absent from many of these discussions is the iterative nature of writing and thinking and how the development of a paper is often tied to one's identity as a scholar; the situated nature of writing within particular discourses; and the social practice of publishing which includes power inequities and unequal access. For example, editors and reviewers may be biased against non-native speaker writers and reject their work simply because they are not native English speakers [38,39]. The problem is that students who happily try to follow these steps will find that publishing is far from straightforward and is often entangled in the intricacies of subject positions, identity and situated discourses.

Downs [40] is one notable exception in the literature. She writes about the complex intersection of expectations, desires, and practices of writing and publishing from her position as a student. She acknowledges the identity-defining nature of writing and publishing: "Achieving published-author status was, to my mind, a mark of belonging to an academic community" [40] (p. 43). She also shows, quite effectively, how puzzling the publishing process was to her. There was little explicit learning in her program on publishing genres or the publishing process. She stumbled her way through to submitting a paper and many months later received a two-line rejection with little explanation of why it was rejected. Her breakthrough happened because of a mentor who stepped in to mediate her publishing journey.

Another exception in the literature is Stoilescu and McDougall [41], who begin their paper by commenting: "Few students, even those registered in doctoral programs, engage in formal academic writing at a level sufficient enough to get accepted in quality peer-reviewed journals" (p. 79). They argue that it is hard for graduate students to focus on publishing while they are occupied with the innumerable tasks required for completing doctoral studies. They acknowledge that scholarly writing is "not linear" (p. 81) and that other issues (family, financial and other commitments) may get in the way. Stoilescu and McDougall [41] also suggest other practices to help one become acclimatised to the publishing world such as writing book reviews, publishing in conference proceedings and becoming a reviewer. They highlight the importance of the social networks that contribute to successful publishing, such as having someone to read a draft paper and provide feedback.

In addition to the 'how to' literature, there is substantial research on academic publishing which is produced by multi-disciplinary researchers from a writing-studies perspective. This research focuses on, for example, the very real challenges students face when trying to publish while studying, writing a dissertation and working long hours [42]. Braine [43], for example, recounts his journey of submitting a paper, being rejected, negotiating that rejection, rewriting substantially and resubmitting, illustrating a less than straightforward publishing path. Lee and Norton [44] show the importance of 'literacy brokers' - people who provide guidance, feedback and access to networks—for beginning scholars (see also [45]). Matsuda [46] reveals the difficulty of writing as a graduate student and the need to develop a discursive voice in his writing that portrayed an identity as an experienced writer/researcher. Kamler [47] shows how the social practice of submission, reviews, revision and resubmission can provide a pedagogical space for learning how to publish. Canagarajah [48] reveals the geopolitical 
inequities in the academic publishing industry and how difficult it is to get published from the margins and/or in Anglophone journals. All of these examples point to writing and publishing as much more complex, more situated and a much less certain and straightforward process.

Learning how to write a paper, getting published and developing confidence in what one is writing happens over many years of failure, success, receiving feedback, being mentored, mentoring, rethinking, rewriting, revising again and becoming familiar with a field of research and with journals within that field. The purpose of this paper is to make the tacit knowledge about academic publishing explicit through the intertwining autoethnographic narratives from an experienced scholar and a doctoral candidate, and to address the broader discourses that complicate our experiences of publishing. However, we are also aware that being explicit depends on context and practice. In the following section, we discuss the situated nature of writing and our academic backgrounds first, and then we identify four themes, we would like to bring to the attention of readers: That to write and publish successfully one needs (1) to be a discourse analyst; (2) to have a critical competence; (3) to be able to write with fluency; and (4) to have emotional intelligence. These four themes, relevant to writing and pedagogy, we offer as a way of contextualizing the 'how-to' information. Using the narratives we explore these themes in detail.

\section{The Situated Nature of Writing}

Education scholar Patti Lather writes about 'getting lost' in the context of her work. She emphasizes the importance of 'not knowing' and the value of "what it means to not be in control and [having] to try to figure out a life" [49] (vii). What she means here is sometimes it's important to stutter through knowing and that getting lost and finding one's way out can be the way through difficult knowledge. For both novice and experienced academic writers, writing for publication can be a complex and difficult process. They may experience many frustrations and failures before finding their own ways of writing. It is important for novice writers to be aware that learning to write takes time and that it is common to struggle with publishing at the beginning. It is also crucial for experienced writers to embrace the feeling of 'getting lost,' of unsettling their authority and expertise, and being open to new ideas as they journey through the ups and downs of a publishing career.

Xiaolin: I am an international student who came to Canada in 2011. I spent two years doing my Master's program in education, and then continued my studies in education for a doctoral degree. I felt so excited when I knew that I was going to become a doctoral student, but I was shocked when I started my first semester. Doing a doctoral program was far more tough and stressful than I expected. The workload was intense and expectation were high. During the first two years of the program, I was completely overwhelmed by the coursework and the comprehensive exam. As a young doctoral student, I did not have much teaching and research experience when I started the doctoral program. Besides, English is my second language, so I had to overcome a lot of language and cultural barriers. I spent a lot of time and energy in adjusting myself to the new learning environment and in meeting all the mandatory requirements of the doctoral program. I had no time to think about publishing, let alone writing papers for publication. Moreover, I did not want to put too much pressure on myself, so I decided not to spend too much time in publishing before finishing my comprehensive exam. Now I wish I had undertaken publishing earlier.

Cecile: I am an international mid-career scholar who moved to Canada from South Africa in 2008. I took up a faculty position in Education in 2011. In the Canadian university system, new hires enter a probationary period of six years. During this time, faculty are expected to perform in three areas: Engagement with scholarly work, teaching excellence and service. Service involves administration, committee work and service to university, local and international communities. Performance review of these three areas is conducted by a Promotions and Tenure Committee, consisting of faculty peers. The committee meets annually and reviews the faculty member's file paying attention to these three areas. If the person is found to have performed satisfactorily at the end of the six years, tenure is 
granted. If tenure is not granted, the individual usually leaves the university. While it is assumed that all faculty will achieve tenure, this is by no means guaranteed. In theory, all three areas are equally important but in practice, research productivity is often the most important criteria assessed. As a result, there is enormous pressure to publish in peer-reviewed journals.

Xiaolin: As a doctoral candidate, "publication" is a word that makes me feel stressed and pressured. I feel reluctant to write for publication because I know getting a paper published is a very competitive process. I may spend a lot of time and effort in writing a paper, but there is no guarantee that my paper will be accepted in a peer-reviewed journal. However, I am also aware of the importance of writing for publication for doctoral students. I am often told that establishing an impressive publication record is key to career success in academia.

Cecile: As a scholar and an immigrant, the pressure to publish (and keep my job/home/place in the country) was enormous. But at the same time, I felt extremely privileged to have the space, time and funding to begin a research program. I had already been reading, researching and teaching in my area of interest for about 10 years, so I embraced research and writing in this new environment with enthusiasm. From the time I first completed an Honours research project, I had always enjoyed doing research. Writing took me a lot longer to get to a stage where I enjoyed it. Writing my PhD thesis was excruciatingly painful. But I'm now at a point where I enjoy writing and publishing. It's not easy-by any means.

The narratives above show the located position of each writer. Those positions are not static or fixed and they change as writers move and shift in the discourse. Xiaolin is a newcomer to research; she has not yet built a research focus. She still has to build a body of knowledge with which she is intimately familiar. Once she has completed her $\mathrm{PhD}$, she will have both of these. But now, as a newcomer to publishing, she is still trying to find her way and is grappling with contextual, cultural and language issues. Cecile is more confident because she is mid-career. She had developed a strong research focus and could draw on successful writing experiences in the past. Although she does not find writing "easy", she has reached a point where she is comfortable with the difficulties of writing and publishing. She did not start her writing career feeling this way. In the sections that follow, we will discuss the four main themes generated from our narratives about academic publishing.

\subsection{Discourse Analysis}

Discourse communities are defined by linguist John Swales [50] as "socio-rhetorical networks that form in order to work towards sets of common goals" (p. 9). In different discourse communities, there are different beliefs, values, norms, and assumptions. Understanding the discourse community that dominates a research area will help writers to unpack the available tacit knowledge. Thomson and Kamler [51] make the point that academic writing is socially situated. What they mean by this is that a writer writes for a reader and that reader is situated in a particular context. The reader's needs will be dependent on that context. For example, if one writes a philosophy paper, then the reader will want to read a paper that follows philosophical ways of knowing, formats that are used in philosophy and referencing systems that are specific to that discipline. Readers expect to see writing that conforms to the rules, expectations, conventions and ways of knowing of their subject or discipline. Each journal has a set of readers or what is otherwise known as a discourse community. Academic publishing is about writing for that discourse community and satisfying their needs. A discourse community is made up of people who understand the language of the discourse. For example, each discipline has particular ways of writing, asking questions and understandings of what counts as knowledge. There are overlaps between disciplines and differences within disciplines but writing a philosophy paper (much more conceptual) is different from writing an education paper (usually more practice-oriented). The audiences for each of these papers are different discourse communities. Discourse communities can vary even within one discipline and they change over time, which is 
why it is important to decipher who the readers are for the journal one intends to send a paper to: Do they want theory? Practice-related research? Specific case-studies? Or generalized broad studies? Decrypting the journal requirements and the discourse community needs is no easy task. As Hyland [52] shows, "there are cultural and geographic variations among disciplines, as different education systems, levels of economic development, and political ideologies come into play" (p. 69). He adds that some disciplines have a high degree of cohesion where there is strong agreement about what counts as knowledge and evidence, while others are much more fluid and open. Hyland [52] continues: "authorship is both constrained and facilitated by the rhetorical options that a community makes available to present ideas and validate knowledge in published text" (p. 69). What he means here is that writing is shaped by the audience's needs. The audience shapes both the format, content and experience of writing. Getting to know a reader, audience or discourse community takes, "time to get a feel for the roles that readers can be expected comfortably to play" [53] (p. 19). The importance of knowing the discourse community is apparent in the narratives that follow.

Xiaolin: In the past two and half years of my doctoral study, I kept the mission of writing for publication in mind, but it was so hard for me to get started... How to get my first paper published has become my biggest concern now. I am very confused about what I should do first because there are many things I am not certain about. I am not sure which journal I should publish in, which type of article I should write, and what topic I can write about ... I also searched online and found several relevant journals in my field, but I do not know how to narrow them down. I aim to find a middle-ranking journal in my field so that it is easier for me to get my paper accepted, but I am still not sure which journal is the most appropriate for me. I wish that I could get advice from people who have published papers so that I can have a better understanding of the various journals in my field. I am also aware that there are different types of articles that I can publish in journals, such as original research and review articles. Do journals usually state that what kind of articles they need? Do they accept more research articles than review articles?

Cecile: I was not a novice academic writer when I took up the position in the faculty of education but I found the move to Canada disrupted my knowledge of publishing. In South Africa, I was familiar with the journals and the publishing industry. When I published internationally, I tended to focus on UK journals. I guess there were synergies in the way we see the world. I could tell which journals were more likely to publish my 'way of knowing' and theoretical perspectives. I could 'read' the journals. In Canada, I initially found myself struggling to interpret journals and finding it difficult to target particular venues. I'm not sure if it is language, disciplinary variations or different use of concepts as Kandlbinder [54] suggests but I still find publishing in USA journals difficult. It was a humbling experience because I had to start new, as a beginner, and learn how to write in this context. One of my routes into publishing here was to write book reviews. The book reviews were easier to write. As I became used to the language of journals, I began to develop confidence. Once I had collected research data in the Canadian context, then I focused on peer-review research articles. I kept a list of journals, mostly developed from the papers I was reading. If I found an article that was relevant to my research, I noted the journal it was published in. I also joined listservs in my field. There are often calls for papers on these listservs.

Even though each of us is located in different positions in our careers, we both experienced a sense of confusion because we were not familiar with the current social and cultural publishing context. To begin publishing, we need to understand the world we are publishing in. Xiaolin expresses her confusion and bewilderment and her inability to get started when faced with the overwhelming tasks of starting the process. Where to even begin? Although her narrative expresses a vulnerability about publishing, she has begun to analyze the discourse by identifying different genres: review and research articles. As an international student, Xiaolin needs to know more about the implicit knowledge of academic publishing in Western countries. According to Curry and Lillis [55], multilingual scholars are under great pressure to publish in English-medium journals that may have different values and 
expectations than multilingual scholars have in their local contexts. Cecile's narrative shows a similar bewilderment when she changed contexts and her previous knowledge of publishing could not be transferred into the new environment. She finds herself juxtaposed between the positions of newcomer and experienced writer.

Both the narratives above reflect the complexity of understanding what readers want. Xiaolin is unsure about how to analyze discourse community needs or whether to write a review or a research paper. Cecile's narrative shows that her understanding of the discourse community changed as she moved contexts and she had to analyze again the discourse communities in her new context. Hyland's [52] advice to writers is "regular exposure to a discourse leads individuals to work out the norm the group favours, so that choices are narrowed to the point where writers don't have to decide on every option available" (p. 69). In other words, Hyland suggests that academic writers need to be discourse analysts who read papers in a journal to discover how they are written for the audience: What format (genre) is used? What did the writer include in the introduction? What language features are used? What methodologies are favoured? What evidence is valued? What kind of knowledge prized? How are research problems formulated? Choosing to follow the IMRD format, for example, is a decision based on whether that genre is appropriate after careful study of the papers published in a particular journal.

Writers also need to write and get feedback from someone who is more familiar with the discourse community. Writing book reviews or conference proceedings papers is one way of learning how to respond to a discourse community. It is also important to "read papers published in past issues of the journals" that a writer targets for their work [56] (p. 138). In this way, they are able to "know the kind of interest of that particular journal readership" [56] (p. 138). As the discourse becomes more familiar, doctoral writers will find that "the discipline's ways of thinking, writing, doing and being become more and more 'natural'" and they will begin to write as 'insiders' [51] (p. 30).

\subsection{Critical Competence}

Critical competence is about critically engaging with the publishing process rather than blindly following 'how-to' instructions. It's about being able to see how one is positioned and then to make choices about how to re-position oneself. Critical competence is essentially about a writer's agency within the existing constraints $[57,58]$.

Xiaolin: As an international student, writing in my second language has been a difficult and time-consuming task for me. Although I have been writing in English for a long time, there are still times that I cannot find the right words or phrases to express myself. As a result, I have to either express myself in a slightly different way or completely remove that idea from my writing. I wish I could be a native English speaker so that I could express ideas freely. When I am writing in my native language, I like to use metaphorical and poetic phrases to make my writing beautiful, but I feel that I am largely restricted while I am writing in English. I think it is not only the language barrier, but also the cultural barrier that makes me struggle with writing. I need to gain more cultural knowledge in order to be less self-doubting about my writing. Since writing is difficult for me, it is time-consuming as well.

Cecile: When I started a career again in Canada, I decided that I only wanted to conduct research and write papers about issues I was interested in. I did not want to get caught up in the "publish or perish" mentality and publish just for the sake of getting a publication. I decided I wanted to be a scholar who thought deeply despite the surrounding pressures to be constantly productive. I haven't always managed this but it is something I value strongly.

Xiaolin: I was very glad to hear that our paper was accepted with minor revisions. However, when I read through the feedback from the reviewers, I found that the comments and suggestions were much more than 'minor' and some of the comments seemed to be tough to answer. I began with 
the problems that I could fix easily, such as the language issues. Then I worked on the comments that I could address by reading more literature. If I wrote a paper solely by myself for the first time, there would be some comments I would not know how to handle properly. Co-writing with an experienced scholar allowed me to learn how to deal with reviewers' comments. When I first received the comments from the reviewers, honestly speaking, I felt very frustrated and overwhelmed, and I wanted to argue against the reviewers for some of the comments. I did not see the necessity of making those changes to the manuscript that I thought was "perfect." Interestingly, however, when I took a deep breath and carefully read through the comments a number of times, I began to understand the reviewers' perspectives. Even when I disagreed, I decided to find a way to integrate both of our ideas. Some of the most difficult comments I left to my co-author. Through observing how she replied to those comments, I learned that I do not have comply with all the reviewers' comments. If I disagree with a reviewer's comment, I just need to provide evidence to support my argument. If I come across a comment that I really disagree with in the future, I think I will have the courage to argue against the reviewer and express my own ideas.

Xiaolin is new to publishing and it is not uncommon for newcomers to feel inadequate or unsure of themselves. Xiaolin's narrative shows her struggles with writing in English, not only at the level of linguistics but also in terms of cultural understanding. She feels positioned as a perpetual beginner because of her perceptions of language proficiency. However, her focus on the 'cultural' shows her understanding of her audience and discourse community needs. While Xiaolin is still in the beginning stages of developing critical competence, with her recognition of her position, her growing confidence and perhaps the help of literacy brokers, she will begin to explore her own agency. She's anticipating writing to an audience in Canada who have a particular understanding of the world and who are proficient in English. Canagarajah [48] and Hyland [52] both show the prestige accorded to publishing in English and the politics that surround this. As Canagarajah [48] states: "the hegemony of Western academic journal is so complete that the superiority ascribed to them has somewhat been internalised by periphery scholars themselves" (p. 37). While English-speaking doctoral students can learn how to publish by writing book reviews or publishing in conference proceedings and gradually immerse themselves in the language, conventions and discourses of publishing, multilingual scholars face the challenge of not being able to access these discursive practices and, as such, they face a geolinguistic disadvantage. Publishing from the periphery, where one is peripheral to the discourse, linguistically or geographically is particularly difficult. Canagarajah [48] shows the inequities in the way academic knowledge is constructed and legitimized.

Cecile's narrative shows her deliberate decision-making around the writer/scholar she wants to be despite prevailing discourses that may push her in a different direction. Critical competence is about understanding our positions in the publishing world and manoevering or negotiating around these positions. It means, using narrative to create new stories and subject positions and it means resisting dominant hegemonies. Xiaolin's second narrative piece describes her reaction to the often intimidating and demoralizing peer review process. She articulates that she felt 'overwhelmed' and 'frustrated' and did not want to make changes. She mediated these initial feelings by giving herself time to come to terms with the reviewers' criticisms. She also found a way to skillfully integrate the reviewer's comments while not always complying. Although she might not have expressed her disagreement with reviewers in this first experience, she recognizes that in the future she will be able to counter reviewer's comments if she needs to. In this narrative, she recognizes the value of the review process in improving the paper but is aware that she can negotiate her responses. This is critical competence. Understanding the discursive nature of publishing is a first step in developing critical competency. Finding literacy brokers (see [45,59]), writing mentors, who can help with challenging dominant conceptions of multilingual writing and the peer review process; finding writing companions and writing together; and publishing in international journals that have a truly international board are all avenues for newcomers to take. 


\subsection{Writing Fluency}

Writing papers for publication requires a certain amount of writing fluency, which generally refers to the ability to "[produce] written language rapidly, appropriately, creatively, and coherently" [60] (p. 99). Writers who lack writing fluency may not be able to write when they want to write, and may agonize over every word or sentence. Therefore, developing writing fluency is important for anyone who wishes to publish papers productively.

Cecile: When I begin a paper, I usually think of an idea and an audience together. For example, I think that doctorate students would really like to know how to publish, I have some ideas on that from teaching or data from research, so which journal would best reach that audience? Once I have found a journal (often I'll have a list of 3), then I'll read the journal specifications and notes for authors. I'll read other papers in the journal, sometimes even finding papers that I can refer to and build on in my paper. I don't always get the journal choice right and sometimes I'll be totally off and the paper will be rejected but I've learned to just move on to the next journal and to keep going with the process.

I spent a lot of time thinking, reading and conducting research before I begin writing. When I do start writing, I write quickly and messily. Often I don't know how the paper is going to develop. I just have a key message, some data and a bunch of research articles or notes. It's in the writing that everything comes together. I don't worry about grammar or style when I begin writing. My focus is to get the story down in some coherent form. I set aside time to write the first draft. Then I just write. I suspend criticism until the draft is done. Of course, I always have thoughts like: that's stupid; how can you write that; this will never get published, etc., but I don't pay attention to these thoughts until the first draft is done. I find that if I'm writing often then the words come more easily. If I'm not writing often, then it is very hard not to write clumsily. But I have learned that my initial criticisms are often not accurate so I suspend them and allow the paper to develop messily. Once I have a draft, then I fix it up. In the revision phase, I'll do more reading, following up on sources. I'll strengthen the narrative, the story of the paper. I'll fill in gaps and provide thick description where it is needed. I'll revise and edit until I feel that I can't do anymore. At this point I'll get a colleague to read the paper and review it for me. That often helps me to move away from a nearsighted perspective and to get some distance. After that, I make sure the paper conforms to the journal requirements and send it off. This sounds like an easy process but it doesn't show the frustration, vulnerability or determination that goes into producing a paper.

Xiaolin: The problem with my writing was that I put too much emphasis on choosing the proper words or phrases and making each sentence well structured while writing, which tended to slow me down and prevent me from generating new ideas. Now I realize that I do not have to edit and rewrite while I am writing for the first time. I think free writing is a useful writing strategy since it helps me write down my ideas first before considering the language problems that may appear in my papers. It also allows my thoughts to flow freely and helps me generate more ideas and thoughts than I originally thought.

Writing is not a single coherent practice. Not only are writing practices different across individuals but they are different with each writing event. Although Cecile outlines her 'usual' practice in her narrative, how writing happens depends on the paper she is trying to write, her familiarity with the topic or audience, her confidence levels, her position in the academic hierarchy and so on. Richardson [61] argues that "how we are expected to write affects what we can write about" (p. 7). She advocates for writing as a form of inquiry rather than writing as a form of reporting. She writes, "I had been taught, as perhaps you were as well, not to write until I knew what to say, that is, until my points were organized and outlined" [62] (p. 960). She explains that writing instruction is itself a product of socio-cultural contexts and she argues that not all writers benefit from such instruction because "they undercut writing as a dynamic creative process" and they undermine the 
confidence of newcomers [62] (p. 960). Writing as inquiry acknowledges that researchers construct knowledge about their research and themselves as they write. Writing is not something that happens at the end of a research project, it is the way we come to know our research [62,63]. As Xiaolin points out, the strategy of freewriting helps her formulate more thoughts and ideas than she originally thought. Elbow [64] suggests that "freewriting doesn't just get words on paper, it improves thinking" (p. 87). Writing without stopping for a set period of time allows us to "have dialogues with ourselves," and dialogue is regarded as "the most generative and fruitful form of discourse for thinking" [64] (p. 87). Through having dialogues with ourselves in the writing process, we can deepen our understanding of a certain topic and enrich our thinking. Writing is used to make sense, to theorize and to produce knowledge: "writing forces us to textualize the rigorous confusion of our thinking" [65] (p. 1). In other words, we learn to write through writing and we discover what we know in the writing. We suggest that newcomers try writing as inquiry and freewriting as strategies for writing fluently and finishing writing tasks. Ask yourself as you write: What do I want to say? Why is this important to write? Why do I want readers to read this? How can I write this so that my reader will be able to understand what I mean? Why does this research matter? (see [66]).

\subsection{Emotional Tensions}

Writing in academic contexts, more than in others, is often closely tied to emotions. Bosanquet and Cahir [67] show how this is particularly relevant to doctoral students who are developing their identities as writers and scholars. Emotions surface because of the "intensely personal relationship with the self during the writing process" [68] (p. 272). Feelings of self-doubt, anxiety and dread are often experienced by doctoral students. These feelings can be debilitating and can delay the writing process considerably. In Cameron et al. [68] study, students articulated feelings of fear, insecurity, being judged, extreme pressure, fear of exposure, lack of confidence, hopelessness and vulnerability. In this study, students were able to easily identify emotional lows but were quiet on emotional highs. Often students feel that the negative emotions they experience are individual characteristics and are the consequence of their own inadequacies or failings. They are "surprised and relieved to hear their feelings about writing are shared by others" [68] (p. 273). Normalising these feelings, as part of the writing process, is reassuring.

Negative emotions are common because perceptions of self-esteem and 'intelligence' are often tied to perceptions of quality writing. Additionally, academic contexts are filled with measures of performance assessment. Peer review is the most widespread form of assessment. When writing is assessed, the writer often feels that the self, self-worth and intellect are being judged as well. Academic contexts thrive on critique and criticism, some of which can be severe and unforgiving. These external criticisms often feed into an internal critical voice that combines both real and imagined feedback until it becomes Godzilla trashing over any writing the writer produces. It is important to manage this internal criticism so that it does not become all-consuming and prevents the writer from writing at all [69].

Xiaolin: Another barrier that prevents me from starting to write papers for publication is lack of confidence. I feel reluctant to write for publication because I am not very confident in my writing ability and I am afraid that my manuscript will be rejected. I know that the rejection rates for journal publishing are very high, so I am worried that my manuscript cannot compete with the manuscripts from other researchers and scholars who are more experienced in the field. There is often a negative voice in my mind, if there is little chance of getting my paper accepted, why should I spend so much time and energy writing the paper? I am fully aware that it is an excuse for not putting effort into writing for publication, but it is hard for me to get rid of this idea. Moreover, I subconsciously avoid doing things that may hurt my feelings. I know the rejection will make me upset, so I feel reluctant to give it a try. In fact, my biggest obstacle is myself. I am not confident in myself and I am not brave enough to do challenging things. My fear of failure keeps me from trying new things. 
Cecile: I've developed confidence over time. I've had times of crisis, though. There was one time in particular when I received a scathing review and my confidence was knocked badly. If I hadn't already had publications, I'm not sure I would have recovered. But because I knew that some people found my work interesting and exciting, I was able to let that review go and not let it shape the writer I am. I have also received rejections from very kind reviewers and editors who have taken the time to show me how to improve the paper. So I've learned that rejection is part of the publishing process. I've also learned a lot from reviewing papers myself and being in the position of accepting or rejecting a paper.

In her narrative, Xialoin raises the issue of the self-criticism she experiences and the perception that she may be rejected. She quite rightly does not want to put herself in a position where she will be vilified or disparaged. Both external and self-criticism can cripple a writer. Writing anxiety is a common emotion among academic writers [69]. Feelings of anxiety about oneself as a writer, the writing task and reader often disrupt the writing process. The more complex or important the task, the more the writer will feel anxious and want to avoid that task. Cecile identifies how confidence is developed over time through publishing. She also is able to recognize that the process of publishing also involves rejection. Productive scholars will not take the rejection or harsh criticism personally and they do not let rejection stop them from pursuing their academic career [70]. Sullivan [70] points out that "[p]ublishing rejection is not a mark of failure. Journals that have high rejection rates simply cannot accommodate all who submit, regardless of the quality of the paper" (p. 137). Besides, being open to external criticism could be beneficial and improve our writing.

Cameron et al. [68] suggest that it is important to recognize and articulate the emotions one feels when writing. They suggest two strategies: (1) reassure yourself that these feelings are part of the process and are shared by experienced writers; and (2) practice confronting your fears by sharing writing regularly to get feedback [68]. Other strategies include writing about the emotions you feel, getting a colleague to mediate critical feedback on your writing for you, and working together in groups to see how other people deal with criticism [69]. Bosanquet and Cahir [67] argue that, "becoming a writer is a state of always feeling stuck for various reasons" (p. 146). They continue on to suggest that perhaps that it is the state of getting stuck that we need to value for it often enables conceptual threshold crossings, if we persist.

Xiaolin proposes a solution to her writing anxiety:

Xiaolin: I think finding a partner might be a good way to improve my motivation for publishing. If I can have a reliable partner to publish together, we will support and encourage each other. I will also write more efficiently since I do not want to let my partner down. Writing is a lonely process, so is the whole doctoral program. It seems that no teamwork is required in a doctoral program and every doctoral student is supposed to do his or her own individual work. I have been experiencing a strong sense of isolation during my doctoral program.

Xiaolin expresses her desire for collaborating with others when she writes for publication. For doctoral students, collaborating with more experienced writers can be a good way to ease their stress and anxiety of publishing. Kamler [71] investigated how doctoral students in science and education learned about academic publishing through co-authoring with their supervisors. The study suggests that co-authorship with supervisors plays an important role in enhancing doctoral students' confidence in publishing, helping them publish more productively, and encouraging them to persevere with publication when receiving rejections. However, not all doctoral students receive enough support to learn how to publish productively in academic journals. Kamler [71] urges that, "the issue of doctoral publication requires serious pedagogical attention from the higher education community" (p. 293).

\section{Conclusions}

In this paper, we have attempted to make our individual and shared writing processes and concerns more apparent. We began by discussing the literature on 'how to' publish and we argued 
that although these articles can be useful as a starting point, they present a picture of publishing as a straightforward procedure where anyone can publish if they follow the steps. We suggest that writing and publishing is a situated social practice that is far from linear. Instead it is tied to subject-positions within the discourses we write, to publishing access and inequities and to the way we, and the disciplines we write for, view knowledge. Using autoethnographic methodologies, we used our narratives to try to make explicit the complexities and the messiness of writing and publishing, while at the same time acknowledging that it may not be possible to be totally 'explicit' because knowing comes from participating in the practices of a discourse. It is only through writing, choosing a journal, sending papers off to be reviewed, receiving feedback, revising and resubmitting that one begins to learn the process. Sometimes getting lost is part of the learning process. We developed four themes in our understanding of writing and publishing to help make this situated practice more explicit. We feel that published writers are discourse analysts who are able to evaluate the journal and discourse they wish to publish in for genre, language and epistemologies and then adapt their writing to suit that journal. Productive writers also have a critical competency where they can assess their position in the discourse and then reposition themselves. Writers also need writing fluency to get papers finished. Finally, published writers need emotional intelligence to manage the environment of criticism and critique. We emphasized that since writing is a social practice and we need literacy brokers, mentors, colleagues and writing partners to help us negotiate a successful path. Successful writing is not done alone.

Acknowledgments: Funding was provided by the Faculty of Education and Memorial University to produce this paper.

Author Contributions: Cecile Badenhorst and Xiaolin $\mathrm{Xu}$ conceived and designed this paper, both authors contributed narratives, conducted analyses and wrote the paper.

Conflicts of Interest: The authors declare no conflict of interest.

\section{References}

1. Guerin, C. Connecting the dots: Writing a doctoral thesis by publication. In Research Literacies and Writing Pedagogies for Masters and Doctoral Writers; Badenhorst, C.M., Guerin, C., Eds.; Brill Publishing: Leiden, The Netherlands, 2016; pp. 31-50.

2. Aitchison, C.; Kamler, B.; Lee, A. Publishing Pedagogies for the Doctorate and Beyond; Routledge: London, UK; New York, NY, USA, 2010.

3. Jalongo, M.R., Boyer, W., Ebbeck, M., Eds.; Writing for Scholarly Publication as "Tacit Knowledge": A Qualitative Focus Group Study of Doctoral Students in Education. Early Child. Educ. J. 2014, 42, 241-250.

4. Hatch, J.A.; Benner, S.M. From the Editors: Writing for Publication in Scholarly Journals. J. Early Child. Teach. Educ. 2012, 33, 205-207. [CrossRef]

5. Badenhorst, C.M., Guerin, C., Eds.; Research Literacies and Writing Pedagogies for Masters and Doctoral Writers; Brill Publishing: Leiden, The Netherlands, 2016.

6. McGrail, M.R.; Rickard, C.M.; Jones, R. Publish or perish: A systematic review of interventions to increase academic publication rates. High. Educ. Res. Dev. 2006, 25, 19-35. [CrossRef]

7. Kamler, B.; Thomson, P. Helping Doctoral Students Write: Pedagogies for Supervision; Routledge: New York, NY, USA, 2006.

8. Ellis, C.; Bochner, A.P. Autoethnography, personal narrative, reflexivity. In Handbook of Qualitative Research, 2nd ed.; Denzin, N.K., Lincoln, Y.S., Eds.; Sage: Thousand Oaks, CA, USA, 2000; pp. 733-768.

9. Starr, L. The use of atuoethnography in Educational Research: Locating who we are in what we do. Can. J. New Scholars Educ. 2010, 3. Available online: http://cjnse.journalhosting.ucalgary.ca/ojs2/index.php/cjnse/ article/viewFile/149/112 (accessed on 6 September 2012).

10. Chang, H. Autoethnography as Method; Left Coast: Walnut Creek, CA, USA, 2008.

11. Ngunjiri, F.W.; Hernandez, K.A.; Chang, H. Living autoethnography: Connecting life and research. J. Res. Pract. 2010, 6, E1. Available online: http://jrp.icaap.org/index.php/jrp/article/view/241/186 (accessed on 18 February 2013). 
12. Hernández, F.; Sancho, J.M.; Creus, A.; Montané, A. Becoming university scholars: Inside professional autoethnographies. J. Res. Pract. 2010, 6, M7. Available online: http://jrp.icaap.org/index.php/jrp/article/ view/204/188 (accessed on 18 February 2013).

13. Franlkin Klinker, J.; Todd, R.H. Two autoethnographies: A search for understanding of gender and age. Qual. Rep. 2007, 12, 166-183.

14. Pelias, R.J. The academic tourist: An autoethnography. Qual. Inq. 2003, 9, 369-373. [CrossRef]

15. Mizzi, R. Unraveling researcher subjectivity through multivocality in autoethngraphy. J. Res. Pract. 2010, 6, M3. Available online: http://jrp.icaap.org/index.php/jrp/article/view/201/185 (accessed on 18 February 2013).

16. Denzin, N.K. Analytic Autoethnography, or Déjà Vu all Over Again. J. Contemp. Ethnogr. 2006, 35, 419-428. Available online: http:/ /jce.sagepub.com/content/35/4/419 (accessed on 15 March 2016). [CrossRef]

17. Arnold, J. The Self as Data: A Qualitative Methodology. J. Educ. Dev. Psychol. 2011, 1, 65-73. [CrossRef]

18. Jones, A. Seeing the messiness of academic practice: Exploring the work of academics through narrative. Int. J. Acad. Dev. 2011, 16, 109-118. Available online: http://dx.doi.org/10.1080/1360144X.2011.568282 (accessed on 15 March 2016). [CrossRef]

19. Etherington, K. Becoming a Reflexive Researcher: Using Our Selves in Research; Jessica Kingsley Publishers: London, UK; Philadelphia, PA, USA, 2004.

20. Aslam, H.D.; Jalalian, M. Writing for academic journals: A general approach. Electron. Phys. 2012, 4, 474-476.

21. Derntl, M. Basics of research paper writing and publishing. Int. J. Technol. Enhanced Learn. 2014, 6, 105-123. [CrossRef]

22. Dimitroulis, G. Getting published in peer-reviewed journals. Int. J. Oral Maxillofac. Surg. 2011, 40, $1342-1345$. [CrossRef] [PubMed]

23. Dixon, N. Writing for publication-A guide for new authors. Int. J. Qual. Health Care 2001, 13, $417-421$. [CrossRef] [PubMed]

24. Driscoll, J.; Driscoll, A. Writing an article for publication: An open invitation. J. Orthop. Nurs. 2002, 6, 144-152. [CrossRef]

25. Happell, B. Responding to reviewers' comments as part of writing for publication. Nurse Res. 2011, 18, 23-27. [CrossRef] [PubMed]

26. Sollaci, L.B.; Perreira, M.G. The introduction, methods, results, and discussion (IMRAD) structure: A fifty year survey. J. Med. Libr. Assoc. 2004, 92, 364-367. [PubMed]

27. Kuteeva, M.; McGrath, L. The theoretical research article as a reflection of disciplinary practices: The case of pure mathematics. Appl. Linguist. 2015, 36, 215-235. [CrossRef]

28. Lin, L.; Evans, S. Structural patterns in empirical research articles: A cross-disciplinary study. Engl. Specif. Purp. 2012, 31, 150-160. [CrossRef]

29. Björk, B.; Solomon, D. The publishing delay in scholarly peer-reviewed journals. J. Informetr. 2013, 7, 914-923.

30. Jackson, J.F.L.; Nelson, J.R.; Heggins, W.J.; Baatz, C.M.; Schuh, J.H. Guidelines for Writing for Publication: Demystifying the Process. Coll. Univ. 1999, 75, 11-14.

31. Denehy, J. Publishing an article in the Journal of School Nursing: An overview of the publication process. J. Sch. Nurs. 2006, 22, 307-309. [CrossRef] [PubMed]

32. Harper, F.D. Writing Research Reports and Scholarly Manuscripts for Journal Publication: Pitfalls and Promises. J. Negro Educ. 2006, 75, 322-340.

33. Herbert, J. Further thoughts on writing for publication. Rehabil. Educ. 2007, 21, 71-72. [CrossRef]

34. Klingner, J.K.; Scanlon, D.; Pressley, M. How to publish in scholarly journals. Educ. Res. 2005, 34, 14-20. [CrossRef]

35. McDermott, R.J. Getting published-What editors and reviewers seek from authors. Am. J. Health Educ. 2009, 40, 2-4. [CrossRef]

36. Glasper, E.A.; Peate, I. Writing for publication: Science and healthcare journals. Br. J. Nurs. 2013, 22, 964-968. [CrossRef] [PubMed]

37. Lunt, N.; Davidson, C. Journey to the Centre of the (Academic) Universe: 20 Steps on Getting Published in Journals. Politics 2000, 20, 43-50. [CrossRef]

38. Flowerdew, J. Discourse community, legitimate peripheral participation, and the non-native English-speaking scholar. TESOL Q. 2000, 34, 127-150. [CrossRef] 
39. Flowerdew, J. Attitudes of journal editors to nonnative speaker contributions. TESOL Q. 2001, 35, 121-150. [CrossRef]

40. Downs, Y. Through the Looking Glass: Publishing in Peer-Reviewed Academic Journals. Power Educ. 2011, 3, 39-51. [CrossRef]

41. McDougall, D.; Stoilescu, D. Starting to publish academic research as a doctoral student. Int. J. Dr. Stud. 2010, 5, 79-92.

42. Casanave, C. Dovetailing under impossible circumstances. In Publishing Pedagogies for the Doctorate and Beyond; Aitchison, C., Kamler, B., Lee, A., Eds.; Routledge: London, UK; New York, NY, USA, 2010; pp. 47-63.

43. Braine, G. Negotiating the gatekeepers: The journey of an academic article. In Writing for Scholarly Publication; Casanave, C., Vandrick, S., Eds.; Lawrence Erlbaum: Mahwah, NJ, USA, 2003; pp. 73-90.

44. Lee, E.; Norton, B. Demystifying publishing: A collaborative exchange between graduate student and supervisor. In Writing for Scholarly Publication; Casanave, C., Vandrick, S., Eds.; Lawrence Erlbaum: Mahwah, NJ, USA, 2003; pp. 17-38.

45. Lillis, T.; Curry, M.J. Professional academic writing by multilingual scholars: Interactions with literacy brokers in the production of English-medium texts. Writ. Commun. 2006, 23, 3-35. [CrossRef]

46. Matsuda, P. Coming to voice: Publishing as a graduate student. In Writing for Scholarly Publication; Casanave, C., Vandrick, S., Eds.; Lawrence Erlbaum: Mahwah, NJ, USA, 2003; pp. 39-51.

47. Kamler, B. Revise and resubmit: The role of publication brokers. In Publishing Pedagogies for the Doctorate and Beyond; Aitchison, C., Kamler, B., Lee, A., Eds.; Routledge: London, UK; New York, NY, USA, 2010; pp. 64-82.

48. Canagaraja, A.S. A Geopolitics of Academic Writing; University of Pittsburgh Press: Pittsburgh, PA, USA, 2002.

49. Lather, P. Getting Lost; State of New York Press: Albany, NY, USA, 2007.

50. Swales, J.M. Genre Analysis: English in Academic and Research Settings; Cambridge University Press: Cambridge, UK, 1990.

51. Thomson, P.; Kamler, B. Writing for Peer Reviewed Journals: Strategies for Getting Published; Routledge: London, UK; New York, NY, USA, 2013.

52. Hyland, K. Academic Publishing: Issues and Challenges in the Construction of Knowledge; Oxford University Press: Oxford, UK, 2015.

53. Ong, W.J. The writer's audience is always a fiction. Mod. Lang. Assoc. 1975, 90, 9-21. [CrossRef]

54. Kandlbinder, P. Signature concepts of key researchers in North American higher education teaching and learning. High. Educ. 2015, 69, 243-255. [CrossRef]

55. Curry, M.J.; Lillis, T.M. Multilingual scholars and the imperative to publish in English: Negotiating interests, demands, and rewards. TESOL Q. 2004, 38, 663-688. [CrossRef]

56. Cheung, Y.L. First publications in refereed English journals: Difficulties, coping strategies, and recommendations for student training. System 2010, 38, 134-141. [CrossRef]

57. Badenhorst, C.; Moloney, C.; Rosales, J.; Dyer, J.; Ru, L. Beyond deficit: Graduate student research-writing pedagogies. Teach. High. Educ. 2014, 20, 1-11. [CrossRef]

58. Bruce, I. Theorising Tertiary Writing Instruction: Accounting for the Process, Postprocess, Genre and Critical Literacies Approaches. In Proceedings of the TWN Biennial Colloquium: From Here to There, Auckland University of Technology, Auckland, New Zealand, 2-3 December 2008.

59. Li, Y.; Flowerdew, J. Shaping Chinese novice scientists' manuscripts for publication. J. Second Lang. Writ. 2007, 16, 100-117. [CrossRef]

60. Latif, M.M.A. What Do We Mean by Writing Fluency and How Can It Be Validly Meansured? Appl. Linguist. 2013, 34, 99-105. [CrossRef]

61. Richardson, L. New writing practices in qualitative research. Sociol. Sport J. 2000, 17, 5-20.

62. Richardson, L.; St. Pierre, E.A. Writing: A method of inquiry. In Collecting and Interpreting Qualitative Materials, 3rd ed.; Denzin, N.K., Lincoln, Y.S., Eds.; Sage: Los Angeles, CA, USA, 2008; pp. 473-499.

63. Richardson, L. Writing: A method of inquiry. In Collecting and Interpreting Qualitative Materials, 2nd ed.; Denzin, N.K., Lincoln, Y.S., Eds.; Sage: Los Angeles, CA, USA, 2000; pp. 923-948.

64. Elbow, P. Everyone Can Write Essays toward a Hopeful Theory of Writing and Teaching Writing; Oxford University Press: New York, NY, USA, 2000. 
65. St. Pierre, E.A. Writing as a method. In Blackwell Encyclopaedia of Sociology. Ritzer, G., Ed.; Blackwell Reference Online. 2007. Available online: http://www.sociologyencyclopedia.com/subscriber/tocnode?id= g9781405124331_chunk_g978140512433129 (accessed on 16 November 2010).

66. Selwyn, N. 'So what?' ... a question that every journal article needs to answer. Learn. Media Technol. 2014, 39, 1-5. [CrossRef]

67. Bosanquet, A.; Cahir, J. 'What feelings didn't I experience!': Affect and identity in PhD writing. In Research Literacies and Writing Pedagogies for Masters and Doctoral Writers; Badenhorst, C.M., Guerin, C., Eds.; Brill Publishing: Leiden, The Netherlands, 2016; pp. 132-148.

68. Cameron, J.; Nairn, K.; Higgins, J. Demystifying academic writing: Reflections on emotions, know-how and academic identity. J. Geogr. High. Educ. 2009, 33, 269-284. [CrossRef]

69. Badenhorst, C.M. Productive Writing: Becoming a Prolific Academic Writer; Van Schaik: Pretoria, South Africa, 2010.

70. Sullivan, D. Publication Anxiety: Emotion and the Stages of Publishing in the Library and Information Science Literature. Aust. Libr. J. 2012, 61, 133-141. [CrossRef]

71. Kamler, B. Rethinking doctoral publication practices: Writing from and beyond the thesis. Stud. High. Educ. 2008, 33, 283-294. [CrossRef]

(C) 2016 by the authors; licensee MDPI, Basel, Switzerland. This article is an open access article distributed under the terms and conditions of the Creative Commons Attribution (CC-BY) license (http://creativecommons.org/licenses/by/4.0/). 